\title{
Adaptation and reconstruction of the stations on the Finland railway road
}

\author{
Ekaterina Vozniak $^{1 *}$, Alisa Burgundosova ${ }^{1}$ and Anna Kopytova ${ }^{2}$ \\ ${ }^{1}$ Saint Petersburg State University of Architecture and Civil Engineering (SPSUACE), 2-nd \\ Krasnoarmeiskaya St. 4, 190005 St. Petersburg, Russia \\ ${ }^{2}$ Tyumen Industrial University, Volodarskogo str., 38, Tyumen, 625000, Russia
}

\begin{abstract}
The article deals with the main problems of reconstruction and adaptation to modern conditions of functioning of historical stations of the Finnish railway. The Finnish railway was the first railway created in the Northern direction in the Russian Empire. The article outlined historical information and the existing state of the preserved railway pavilions. The characteristic features of functioning and the reasons of destruction and degradation of buildings of railway stations are analyzed. Herein defined and proved necessity of reconstruction and adaptation of railway stations on the territory of Russia, consisting in a complex combination of different types of social functions. Design solutions include restoration, change of building function, reconstruction of structural and engineering structure of buildings, restoration of facades and historical interiors, development of improvement zones around railway stations.
\end{abstract}

\section{Introduction}

At present, the potential of historical railway stations is not used effectively, buildings are being demolished, their architectural appearance is distorted. To preserve the integrity of the historical and functional appearance of the railway pavilions it is necessary to adapt them to modern conditions.

The Finnish Railway is a historical railway linking the capital of the Russian Empire (St. Petersburg) and the capital of the Grand Duchy (Helsingfors). At present, a section of the railway from Buslovskaya station to St. Petersburg passes through the territory of the Russian Federation. The condition of railway stations and their adaptation in the territory of Finland and Russia differs significantly.

Historical buildings of the late XIX - early XX century have not been repaired for a long time and their condition is depressing. Railway stations are currently operational stations (with the exception of Dibuny station). However, despite this fact, the area of effective use is extremely small. In most cases, often there is only one waiting room and part of the ground floor are in use.

\footnotetext{
${ }^{*}$ Corresponding author: vozniak65@mail.ru
} 


\section{Methods}

The aim of the study is to analyze the existing problems of adaptation of railway stations and find ways to solve them. Priority tasks are:

- collection and the study of historical materials about the railway pavilions;

- $\quad$ analysis of existing problems;

- development of the concept of adaptation of railway stations;

- development of pilot projects for the reconstruction of railway stations, based on the implementation of which it is possible to test the proposed methods.

\section{Results}

The second half of the XIX century can be characterized as a time of rapid development of railways in the Russian Empire. The need for quality communication between the capital of the empire (St. Petersburg) and the capital of the Grand Duchy (Helsingfors) has been brewing for a long time and was realized only in 1869 [1, p. 24]. The Finnish railway was the very first railway created in the northern direction (St. Petersburg - Riihimäki, Riihimäki - Helsingfors). According to the construction plan [1, p. 23], the road was divided into five districts (parts). The first round included the territory to the Russian - Finnish border. The site was $54 \mathrm{~km}$, and on this site they opened the station "Lanskaya", "Udelnaya", "Pargolovo", which later became "Shuvalov", "Pargolovo", "Levashovo" and "Beloostrov". Later stations "Ozerki", "Grafskaya", renamed "Pesochnoye" and "Dibuny" were added to them. The second district united the stations on the territory of the Karelian Isthmus - then it was called Karelia, and in this area, in addition to the "Rayayoki" border station, only four stations were built to open the way - Terijoki (Zelenogorsk), Raivola (" Roshchino "), Kannelyarvi and Perk-Yarvi (Kirillovskoye). The stations and platforms geographically close to Vyborg Leipasuo and Saynie - belonged to the Third District, and the Vyborg railway station and the stations in the principality belonged to the last two districts (see Fig, 1).

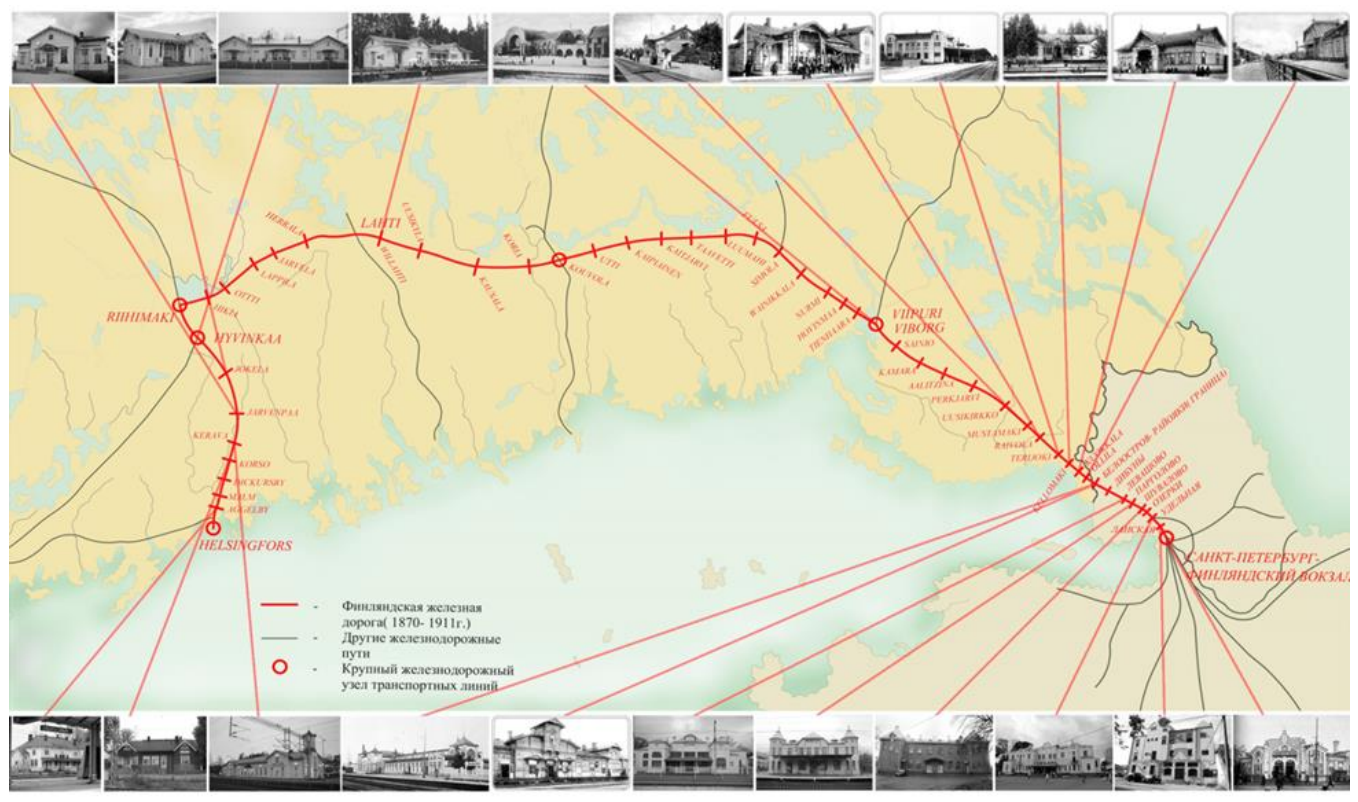

Fig.1. Graphical schemes of US high-rise buildings 
Initially in the 1869-1880s. railway stations were built wooden. Station buildings and other large outbuildings were first made of logs in the form of log cabins, and then they were sheathed and painted with oil paint in yellow. Service buildings were erected in the same way, but covered with red paint. Tol, a building material made of cardboard, impregnated with tar products, was used as the roofing covering of the stations. Station building plans were concise and symmetrical. Despite the simplicity, they nevertheless met the basic functional requirements.

In the $1880 \mathrm{~s}-1890 \mathrm{~s}$. there is a gradual replacement of wooden pavilions with stone buildings, due to the natural destruction of wooden structures. At this time, building of red facing brick, in the style of eclecticism, often two-story. With the exception of large transport hubs (Vyborg, Beloostrov, Riihimyaki), almost all transit stations were built according to standard designs, depending on the class, attendance and workload. The structure of the model plan consisted of a specific layout: the first floor was intended for passengers, the second floor was most often provided as housing for station workers or administration. Depending on the class of the station, a certain number of rooms for passengers were located on the first floor. First class stations included separate rooms for all classes.

At the beginning of the 20th century, railway stations were built in the style of northern modernism. Finnish architect Bruno Ferdinand Granholm was involved in designing projects for station buildings [2, p. 88]. The architectural form of the stations was distinguished by its massiveness, characteristic ornamentation, the use of high roofs, and the asymmetrical arrangement of window openings. Contrasting combinations of textures, color planes, a variety of window openings, the complexity of the roof solution - all this makes the facades in a complex structure that resembles both northern rock landscapes and large-scale medieval buildings. All stone stations are preserved and are in working condition, but at the moment a very large part of them are not in operation and remain abandoned.

You can identify the main problems for the adaptation of railway pavilions, such as:

- insufficiently effective use of historic buildings, caused by the need to adapt to the modern conditions of functioning of the railway;

- $\quad$ insufficient funding for restoration work;

- complexity of coordination and lack of state support;

- the main part of the railway stations, supporting the railway functions (in a greatly reduced volume), does not take into account the possibility of using the modern public function for the adjacent settlement.

The adaptation of stations to modern conditions provides for a set of design works:

- expansion of the building function, consisting in a complex combination of various types of public functions; it is necessary not only to recreate or preserve the historical function, but also to add one or more social functions: an exhibition hall, a restaurant, a cafe, a museum, etc. ;

- repair and reconstruction of buildings in order to increase comfort, which consists of the characteristics of aesthetics, strength, humanity, safety; typical methods of building adaptation are elevator installation, heating device, electrification, installation of air conditioning systems, redevelopment of areas.

\section{Discussion}

Railway stations are currently operational stations (with the exception of Dibuny station). However, despite this fact, the area of efficient use is extremely small - only one waiting hall is used. Only the first floor functions, the 2nd floor - usually - is empty.

The main adaptation function for the 1 st floor of the pavilions should be to preserve the function of the railway station (waiting rooms and ticket offices, administration and technical 
personnel premises), as the most important basic function attracting public flows. On the 2nd floor should be used additional public functions, such as preparing and renting out premises for accommodation:

- cafes or restaurants, which requires solving the problem of the relationship between historical construction and modern sanitary and engineering standards,

- mail or logistics centers for commercial mail,

- administrative and office space,

- search for additional functions, for example, a museum exhibition space (the history of the railway or a given settlement at the station), a center for children's creativity and clubs of interest to adults, stationary cell halls and exhibitions.

The concept of building adaptation involves solving the following problems:

- survey of the object (measurements, photo fixation, examination of existing structures), performing historical, archival and bibliographical research,

- Indication of points and direction of shooting;

- clarification of objects of protection of buildings,

- redevelopment of premises with no historical value,

- solving fire safety issues and evacuation problems,

- installation of passenger and freight elevators,

- redevelopment of attic spaces with partial replacement of the constructions and organization of the premises used,

- repair and restoration of facades, reconstruction of historical interiors,

- solving issues of building engineering,

- improvement of adjacent territories.

SPSUACE in the master's thesis of A. Burgundosova under the guidance of E. Vozniak completed projects for the adaptation of railway stations - Lanskaya, Shuvalovo, Pargolovo, Dibuny

\section{Conclusion}

The basis of the design solution is the expansion of the original utilitarian function of the railway station, as well as in a complex combination of various types of public functions. Design solutions include rebuilding, changing the function of the building, and developing landscaping areas around railway stations. The main priority for the adaptation of the railway station is not only the preservation of architectural components, but also the reconstruction of the holistic historical image of the railway station.

The architectural complex of the railway represents a cultural potential that can serve as the basis for the cultural and economic development of a number of settlements in the Leningrad Region.

\section{References}

1. A. Y. Gusarov From the Finland Station to Vyborg. From the history of the Finnish railway. (Moscow, Tsentrpoligraf, 2016)

2. A. A. Syrov Forgotten sights of the western part of the Karelian Isthmus. From St. Petersburg to the Finnish border: a guide. (Moscow, Publishing Center on Li Count, 2012)

3. Kansallisarkisto; Valtion Rautatitet; Rautatic hallitus, Rautatierakennusasato, Ia. 3. Projekt till jernvag emellah Lahtis-Saimen och Wiborg ar 1860; 55m:1/14E.

4. Kansallisarkisto; Valtion Rautatitet; Rautatic hallitus, Rautatierakennusasato, Ia. 6. TavastehusTammerfors, samt Riihimaki-Lahtis jernvag projekter ar 1869; 55m:1/2. 
5. Kansallisarkisto; Valtion Rautatitet; Rautatic hallitus, Ia.18.UDELNAJA/55m; 3/18.

6. https://terijoki.spb.ru/railway/rw_stations_articles.php

7. https://terijoki.spb.ru/railway/rw_history.php

8. http://www.mikanhuone.com/asemarakennukset.html

9. http://www.aroundspb.ru/karty/234/karper_1966.html

10. http://www.helsinki.fi/kansalaismuisti/vantaa/helpit/uimonen2.htm

11. http://perecheek.narod.ru/perecheek.html

12. https://krisha0703.livejournal.com/28782.html?thread $=615790$

13. https://humus.livejournal.com/3550927.html

14. https://slovo13.livejournal.com/1184521.html

15. http://ozerki-piter.narod.ru/istoriya $2 . h t m l$

16. http://forum.citywalls.ru/topic $845 . \mathrm{html}$

17. http://www.aroundspb.ru/railroad_books.html\#new

18. http://www.citywalls.ru

19. https://terijoki.spb.ru/railway/rw_stations_articles.php

20. https://krisha0703.livejournal.com/57368.html16 